\title{
CULTIVATION OF MEDICINAL HERB HYPERICUM PERFORATUM IN THE LABORATORY CONDITION
}

\author{
Makhsuda Usmonkulovna Nizomova \\ Doctor of Philosophy on Agricultural Sciences (PhD), \\ Senior Teacher of Department of Medical Plants, \\ Tashkent State Agrarian University, University str., 3, Tashkent-100140, Uzbekistan. \\ Mavluda Turgunboevna Yulchieva \\ Associate professor, Candidate of Biological Sciences, Department of Pharmacognosy, \\ Tashkent Pharmaceutical Institute, Tashkent-100190, Uzbekistan \\ Feruza Madiyarovna Dusmuratova \\ Associate professor, Candidate of Biological Sciences, Department of Pharmacognosy, \\ Tashkent Pharmaceutical Institute, Tashkent-100190, Uzbekistan
}

DOI: https://doi.org/10.36713/epra3813

\begin{abstract}
This scientific article presents scientific data on the cultivation of medicinal herb Hypericum perforatum L. in the laboratory condition.

In the laboratory condition, the rate of seed germination was much higher (75\%-78\%) when treated by thermal preparation compare to soaking seeds in water for a day and it was also observed the accelerating seed germination in the stratification with sand.

Sowing seeds with treated solution (concentrated sulfuric acid) and stratification of seeds with sand were found to be able to grow faster, increase the number of foliage, relatively spreading of the root system and ready for field planting in the field conditions

KEYWORDS: seedlings, seed, substrate, biohumus, stratification laboratory, Hypericum perforatum.
\end{abstract}

\section{INTRODUCTION}

The people of the world have been using medicinal plants since ancient times. Great attention is paid to development of science all over the world, including in our Republic. As a result of this, we see a growing number of different drugs in our pharmacies.

One can find of the dried organs of plants which are increasingly widespread.

In recent years natural medicinal plants have been replacing of synthetic drugs.
One of them is the medicinal herbs (Hypericum perforatum L.), which is widely used as a medicinal plant in folk medicine in the world.

This plant is known among the people as the "ordinary hypericum", (Hypericum perforatum L.), yellow tea herbaceous, herbaceous grass, "Far eastern yellow herb" [5].

Hypercicum perforatum L. contains high level of essential oil, anthocyanins, flavonoids (quercetin, hyperoside, rutin), carotene, Vitamin $\mathrm{C}$, organic acids, hypericin and other substances $[2,4]$. 
The fluid that derived from plant juice, flowers, leaves, roots and other parts of the plant have been used as a diuretic in chronic renal, abdominal and bowel diseases, particularly constipation, liver diseases (jaundice, cholecystitis, etc.). Its juice is mixed with honey and used for the treatment of stomatitis, tongue whitening and cracking in children [4].

Therefore, it is necessary to carry out scientific research on these medicinal plant, develop ways to reproduce their seeds and seedlings, develop technologies for cultivation in a cultured environment and expand the cultivation area, and study some biological features, active component and develop agro technologies that suit for the Republican climatic - soil condition and including how to improve reproduction of the medicinal plant from the seedlings are the most prior issues of the day.

\section{MATERIALS AND METHODS}

The object of the research is the department of 'Medicinal plants' Tashkent State Agrarian university, increasing seed germination of the studied medicinal plant (Hypericum perforatum L.) to expand from seedlings.

In conducting experiments, observations, calculations and analyzes were used by B.A.Dospekhov's "Methodology of field experiments (1979) and "Methods of field experiments" (2007) that developed by UzCSRI.

Biological peculiarities of the plant were conducted by methods of T.A.Rabotnov, I.T.Serebryakov while determination of seed germination by M.Firsova.

\section{RESULTS AND DISCUSSION}

In accordance with the experimental system, seeds are prepared from soil, sand and biohumus substrate mixture in the ratio $1: 1: 1$ to prepare Hypericum perforatum $\mathrm{L}$.

The prepared substrate was placed in seedling cassettes (80 cells each).

Thermal treatment of seeds was carried out by means of sowing the seeds within 24 hours, using methods for accelerating seed germination (sulfuric acid) and using stratification of seeds with sand method on March 5, 2019, with 10 seed per cell.

Seeds are sprayed daily with water using a sprayer.

Seeds begin to germinate after 6-8 days depending on the processing method.
The acceleration of the seeds were shown on Table (on March 12, 15).

The obtained data showed that in laboratory conditions, relatively high yields were observed when sowing seeds with concentrated sulfuric acid solution when cultivated by different methods.

In this variant, $13 \%$ of the seeds that germinated 2 days ago (compare to the total sown seeds), and $35 \%$ on the $3^{\text {rd }}$ observation day, $50 \%$ of the germination within 20 days after sowing.

Seed germination with stratification sand did not occur during the $1^{\text {st }}$ and $2^{\text {nd }}$ observation days of the 3 variant.

However, 20 days after sowing (March 20), it was observed that $40 \%$ of seeds germinated.

In the control version of the experiment, when seeds were sown soaking in water for one day and only $11 \%$ of seeds germinated, 20 days after sowing.

This was $39 \%$ lower than the $2^{\text {nd }}$ option and $29 \%$ less than the $3^{\text {rd }}$ option.

In the experiment, seed germination was performed 30 days after the last observation period.

In the control variant germinated seeds were $64 \%$, when treated with sulfuric acid solution $75 \%$ and with stratification sand made up $78 \%$.

In all studied variants, complete germination (100 $\%$ ) was not observed.

The main reason for this is the low biological capacity of the seed of medicinal herb.

In order to continue the laboratory experiments on the cultivation of Hypericum perforatum L. seedlings, one good plant was left in each cassette box (the other plants were removed) followed by the technology of cultivation. During the nursing care watered twice a day (at 9.00 in the morning and at 7.00 in the evening), consuming water for per cassette was 1.2-1.5 liters.

Feeding of seedlings with mineral fertilizers was carried out on May 7, after 37 days of germination.

When feeding the seedlings, $15 \mathrm{~g}$, ammonium nitrate, $10 \mathrm{~g}$ ammonium phosphate and $8 \mathrm{~g}$ of potassium fertilizer were mixed (10 liters of water) and the ready solution was sprayed on the plants.

The experiment ensured the normal growth and development of water and mineral nutrients provided to the Hypericum perforatum L. seedlings. 
Table

Acceleration of the seed germination of Hypericum perforatum $\mathrm{L}$. in the laboratory condition (\%)

\begin{tabular}{|c|c|c|c|c|c|c|c|}
\hline \multirow[b]{2}{*}{ Name of the plant } & \multirow[b]{2}{*}{ Variants } & \multirow{2}{*}{$\begin{array}{l}\text { Seed sown } \\
\text { day }\end{array}$} & \multicolumn{5}{|c|}{ Observation days } \\
\hline & & & 05.03 & 10.03 & 20.03 & 25.03 & 30.03 \\
\hline \multirow{3}{*}{$\begin{array}{l}\text { Medicinal plant } \\
\text { Hypericum } \\
\text { perforatum L. }\end{array}$} & $\begin{array}{c}\text { Sowing seeds with } \\
\text { soaking in water for } \\
\text { a day }\end{array}$ & \multirow{3}{*}{01.03 .2019} & - & - & 11 & 38 & 64 \\
\hline & $\begin{array}{l}\text { Sowing seeds with } \\
\text { solution treatment } \\
\text { of seed germination } \\
\text { accelaration } \\
\text { (concentrated } \\
\text { sulfuric acid) }\end{array}$ & & - & 13 & 35 & 50 & 75 \\
\hline & $\begin{array}{c}\text { Stratification seed } \\
\text { with sand }\end{array}$ & & - & - & 40 & 45 & 78 \\
\hline
\end{tabular}

The growth and development of seedlings grown under laboratory condition, at the beginning of the growing season, sowing the seeds in water the length of foliage was $2 \mathrm{~mm}$ and the number of foliage made up 3 pieces, while the seeds was treated with accelerating stratification sand the length of the foliage was $3 \mathrm{~mm}$ and number of foliage made up $5 \mathrm{~mm}$.

\section{CONCLUSION}

The results of the studies show that the seed germination rate was slightly higher in the laboratory under thermal treatment, such as sowing with a solution that accelerated seed germination (concentrated sulfuric acid) as well as with stratification sand compare to soaking in water for one day $(75-78 \%)$.

Sowing the seed with the accelerating seed germination treatment solution (concentrated sulfuric acid) as well as with stratification sand were discovered to be able to grow faster, increase the number of foliage, relatively deep root system and spreading the root and Hypericum perforatum L. readiness for field planting condition.

\section{REFERENCES}

1. Akhmedov U., Ergashev A., Abzalov A.,Yulchieva $M$. (2009). The technology and ecology of cultivation medicinal plants (Textbook). Tashkent, $175 \mathrm{p}$.

2. Akopov M.E. (1990). Important local medicinal plants and their usage. Tashkent, Medicine, $448 p$.

3. Karimov B.A., Shomakhumudov A. (1993). Medicinal plants that used in modern scientific and folk medicine. Tashkent: HMB named after Avicenna, pp. 86-88.

4. Kholmatov Kh.Kh, Ahmedov U.A. (2007). Pharmacognosy. Tashkent, $492 p$.

5. Names of plants. November 21, 2019 https://www.liveinternet.ru/users/nordanika/post4632 66708 